\title{
Introduced marine species of the North Sea coasts
}

\author{
K. Reise ${ }^{1}$, S. Gollasch ${ }^{2} \&$ W.J. Wolff ${ }^{3}$ \\ ${ }^{1}$ Alfred-Wegener-Institut für Polar- und Meeresforschung, \\ Wattenmeerstation Sylt; D-25992 List, Germany \\ ${ }^{2}$ Institut für Meereskunde, Düsternbrooker Weg 20, D-24105 Kiel, Germany \\ ${ }^{3}$ Rijksuniversiteit Groningen, Mariene Biologie, Postbus 14, \\ NL-9750 AA Haren, The Netherlands
}

\begin{abstract}
About 80 non-indigenous species are assumed to have been introduced into the North Sea by transoceanic shipping and aquaculture. The number is certainly underestimated as most small organisms received insufficient attention at the species level. Also, the seafaring tradition of the North Sea countries is much longer than our biological surveys are. Most exotic invertebrates originate from the western Atlantic and were introduced by shipping, while most algae stem from the Pacific and came with the introduced oysters. A peak of newcomers was observed in the 1970s. Most of the arrivals became established in brackish environments, at harbor sites and in the vicinity of oyster farms, fouling on hard substrates or living as epibionts. A few live in sediments, are holoplanktonic or are parasites. At the open coast, approximately $6 \%$ of the macrobenthic species are exotics, while in estuaries their share is up to $20 \%$. Most exotics have been encountered in the southern North Sea first, and many did not spread further north. About $25 \%$ of the established non-natives are widespread and attain locally high abundances. As a consequence, some inshore habitats are entirely dominated by exotics. The overall effect on the ecosystem seems to be more additive than one of displacement. This suggests that the coastal biota of the North Sea are quite capable of accommodating newcomers. However, this is no guarantee that the next introduced species may not cause severe ecological change or economic harm. There is a need to minimize the risk of unintentional introductions by ballast water treatment and by adhering to quarantine procedures in aquaculture. Current research on exotics in the North Sea is regarded as inadequate for proper evaluation and management requirements.
\end{abstract}

\section{INTRODUCTION}

Maritime traffic across the oceans and culturing of non-native organisms at the edge of the sea contributed to the spread and establishment of an ever increasing number of exotic species in coastal and brackish water environments. Exotic species of the North Sea are here operationally defined as species occurring only outside the region of the Atlantic coast of Europe (Gibraltar to North Cape); hence Mediterranean and Ponto-Caspian species are considered as exotics. We further restrict this overview to species which have presumably arrived by means of human transport, both intentional as well as unintentional introductions. Boundaries of the North Sea are defined according to the North Sea Task Force (1993), which includes the Channel region in the south, the Skagerrak and Kattegat in the east, and the Shetland Islands in the north. Species of brackish habitats have been included when a salinity of $>5$ psu is regularly encountered at the sites. 
To regard an exotic species as being established in the North Sea, there must be evidence of continued propagation by more than one generation. In practice, when developing offspring have been observed in more than one season or when the presence of a species clearly exceeds the expected lifetime of an individual, we have considered this as sufficient evidence of successful establishment.

Many of those coastal species which the coastal North Sea has in common with the Mediterranean Sea, the western Atlantic, the northern Pacific or even the southern hemisphere may have crossed the natural barriers of dispersal with the aid of ocean-going vessels or with transports of commercial fishery products. This probably commenced early on with the Mediterranean region. The first expeditions of the Vikings and the Basques to North American shores date back to about A. D. 1000, and for four centuries the North Sea has been connected with almost all coasts of the globe by extensive seafaring. Thus, there is a rich supply of exotic species.

Ships represent floating biological islands, giving rise to a spring tide of potential invaders at the coast where they arrive (Carlton, 1985, 1989; Carlton \& Geller, 1993). Wooden ships have invited boring organisms such as the shipworm Teredo navalis and the gribble Limnoria spp., foulers attached to the ships' hull, and ballast sand or rock were often carried from coast to coast, and adhering organisms had a fair chance to get abroad. Since the introduction of steel-hulled vessels in the 1870 s, ballast water discharges have increased considerably. The probability of establishing self-sustaining populations of non-indigenous species increased with greater volumes of ballast water in larger and faster vessels. A recent study of North Sea and Baltic ports on ships as introducing vectors of exotic species revealed 404 species in samples from ballast water, sediment in the tanks and ship hulls, ranging from unicellular algae to 15-cm-long fishes. About $60 \%$ of these species are non-indigenous to the North Sea and the Baltic (Gollasch, 1996; Lenz et al., in preperation).

Large-scale transfers of oysters between distant coasts commenced as early as the middle of the nineteenth century (Möbius, 1877; Korringa, $1976 \mathrm{a}$, b). These shipments often comprised entire oyster bed communities. Since the 1970 s, more and more oyster transplants originate from enclosed hatcheries (Chew, 1990), and this might eventually close this major gateway of marine introductions. International trade in seafood still forms a risk, however.

Introductions of exotic species have occasionally resulted in striking changes, e.g. the West-Atlantic ctenophore Mnemiopsis leidyi into the Black Sea where it tilted the regional anchovy fishery (Travis, 1993); the tropical green algae Caulerpa taxifolia into the Mediterranean where it is rapidly overgrowing seagrass beds (de Villèle \& Verlaque, 1995; Ceccherelli \& Cinelli, 1997); the Asian bivalve Potamocorbula amurensis into San Francisco Bay where it changed the entire food web structure (Carlton et al,, 1990; Nichols et al., 1990; Kimmerer et al., 1994); the North Sea crab Carcinus maenas showing gigantism and strong predatory effects at the coast of California and Tasmania (Grosholz \& Ruiz, 1995; Hewitt, personal communication); the East-Atlantic periwinkle Littorina littorea causing cascades of ecological changes in the recipient West-Atlantic coastal biota (Brenchley \& Carlton, 1983; Bertness, 1984), and finally various introduced diseases of oysters and fish (Lauckner, 1983; Kinne, 1984) as well as toxic algae in the plankton (Anderson, 1994) have caused trouble and concern in different places around the world. 
The various coasts differ in the number of exotics they have received, in the number of exotics which have become established, and in the effects of the exotics on the native biota (Ruiz et al., 1997). We here attempt a brief overview of introduced species into the North Sea. More extensive reviews covering in part the North Sea region are given by Eno et al. (1997), Jansson (1994) and Nehring \& Leuchs (1999). We here particularly ask the questions: How many became established, where did they come from and at what time were they discovered, by what means did they arrive, and where and how did they fit into the habitats of the native biota? Finally, what is the overall effect and what should be done about it?

\section{HOW MANY EXOTICS IN THE NORTH SEA?}

The number of non-indigenous taxa assumed to have been established in the North Sea amounts to about 80 species (Table 1). This total number is lower than what has been recorded from some estuarine regions in North America, i.e., 116 in Chesapeake Bay, 137 in the Great Lakes and 212 in San Francisco Bay (reviewed in Ruiz et al., 1997), but these studies included organisms from freshwater as well as terrestrial shores and wetlands to a variable extent, while ours is confined to marine and brackish water organisms. The majority of exotics in the North Sea are invertebrates (47), primarily crustaceans, molluscs, polychaetes and hydroids (Table 2). Introduced macroalgae comprise 20 taxa, mostly red and brown ones. Only 12 species of protists are among the assumed exotics of the North Sea.

Of the 80 species listed in Table 1,22 occur preferentially in brackish environments. 'Hotspots' of introduced species are harbor sites and in the vicinity of oyster farms, where they grow or climb on the artificially provided hard substrates. At least 26 species belong to this category. Only about ten of these have diffused onto the rocky shores of the open coast. A frequent mode of life is as epibionts, mostly on molluscs and algae (27 species). Six introduced species are parasites. Of the exotic species seventeen dwell in or on coastal mud and sand. Only ten holoplanktonic species have been recognized as exotics. However, in this group a distinction between introduction and natural drift by oceanic currents is often impossible.

The snail Corambe (obscura) batava, once locally established, has gone again because the habitat has been altered by coastal engineering. Almost all introductions occurred accidentally. Also, the marsh grass Spartina anglica and the amphipod Gammarus tigrinus originate from accidental introductions but were further distributed deliberately in the North Sea region. The bivalves Mercenaria mercenaria, races of Ostrea edulis, Crassostrea gigas, C. angulata and C. virginica were deliberately introduced, but the latter two did not establish reproducing populations (Hedgpeth, 1980; Eno et al., 1997). This is different to the situation in the adjacent freshwater habitats of central and western Europe. Similar to the North Sea, about 80 species have been introduced and became established, but nearly half of these were intended introductions, particularly fish (Kinzelbach, 1995).

The share of exotics in the North Sea biota increases from the offshore part towards the coast, and there it increases further from the open coast towards the estuaries. In the latter, the percentage of exotic species is about 20 (Wolff, 1999). In the waters around 
Table 1. Non-native species established in the North Sea including the Channel and Kattegat regions. Origin: eastern Atlantic outside North Sea (EA), western Atlantic (WA), southern Atlantic (SA), northern Pacific (NP), southern Pacific (SP), Indo-Pacific (IP); + no longer present because habitat has changed; transport known or assumed to have occurred with aquaculture (A) or ships $(S)_{i}$ status: occurring along most of the coasts $(+++)$, in part of the area $(++)$, at one or a few localities (+), primarily in freshwater but extending into brackish estuaries and lagoons (b); ? species of uncertain taxonomic status or which may have arrived also by natural means. References are limited to one or two sources where further information may be obtained: 1 Chapman, 1999; 2 Elbrächter, 1999; 3 Eno et al., 1997; 4 Essink, 1999; 5 Fletcher \& Farrell, 1999; 6 Hayward \& Ryland, 1990; 7 Lauckner, 1983; 8 Maggs \& Stegenga, 1999; 9 Nehring, 1998; 10 Stock, 1993; 11 Thiel, 1968; 12 Wolff, 1999; 13 Zibrowius \& Thorp, 1989; 14 Gollasch \& Riemann-Zürneck, 1996

\begin{tabular}{|c|c|c|c|c|c|}
\hline Taxon & Origin & $\begin{array}{l}\text { First } \\
\text { record }\end{array}$ & $\begin{array}{l}\text { Trans- } \\
\text { port }\end{array}$ & Status & Ref. \\
\hline \multicolumn{6}{|l|}{ Dinophyceae (dinoflagellates) } \\
\hline $\begin{array}{l}\text { ? Gymnodinium mikimotoi } \\
\text { Miyake \& Kominami (syn. G. aureolum, } \\
\text { G. nagasakiensis) }\end{array}$ & NP & 1966 & & +++ & 2,9 \\
\hline Alexandrium leeii Balech & NP & 1995 & & + & 2 \\
\hline \multicolumn{6}{|l|}{ Raphidophyceae } \\
\hline Fibrocapsa japonica Toriumi \& Takano & NP & 1991 & & ++ & 2,9 \\
\hline Chattonella sp. & NP & 1991 & & ++ & 2,9 \\
\hline \multicolumn{6}{|l|}{ Bacillariophyceae (diatoms) } \\
\hline Odontella (Biddulphia) sinensis (Greville) & NP & 1903 & S & +++ & 3,9 \\
\hline Thalassiosira punctigera Castr. & NP & 1978 & $\mathrm{~A} / \mathrm{S}$ & +++ & 3.9 \\
\hline Thalassiosira tealata Takano & NP & 1950 & $\mathrm{~A} / \mathrm{S}$ & ++ & 3,9 \\
\hline ? Thalassiosira hendeyi Hasle \& Fryxell & $\mathrm{SA}$ & 1978 & S & ++ & 3,9 \\
\hline Coscinodiscus wailesii Gran \& Angst & NP & 1977 & $\mathrm{~A} / \mathrm{S}$ & +++ & 3,9 \\
\hline \multicolumn{6}{|l|}{ Phaeophyceae (brown algae) } \\
\hline Sargassum muticum Fensholt & NP & $1960 \mathrm{~s}$ & A & +++ & 3.5 \\
\hline Undaria pinnatifida Suringer & NP & 1986 & $\mathrm{~A} / \mathrm{S}$ & ++ & 3,5 \\
\hline ? Fucus evanescens C.Ag. & NP & 1902 & & + & 5 \\
\hline Colpomenia peregrina Hamel & IP & 1905 & A & +++ & 3,5 \\
\hline Corynophlaea umbellata Kützing & NP & 1990 & $A$ & + & 5 \\
\hline \multicolumn{6}{|l|}{ Rhodophyceae (red algae) } \\
\hline Bonnemaisonia hamifera Hariot & NP & 1890 & A & +++ & 3,8 \\
\hline Asparagopsis armala Harvey & SP & 1950 & A & + & 3,8 \\
\hline Grateloupia doryphora Howe & NP & 1969 & A & + & 3,8 \\
\hline Grateloupia luxurians Gepp & IP & 1947 & A & ++ & 3,8 \\
\hline ? Agardiella subulata Kraft \& Wynne & $?$ & 1973 & A & + & 3,8 \\
\hline Antithamnionella ternifolia Lyle & SP & 1926 & $\mathrm{~S}$ & ++ & 3,8 \\
\hline Antithamnionella spirographidis Schiffner & NP & 1906 & $\mathrm{~S}$ & ++ & 3,8 \\
\hline Dasya baillouviana Montagne & WA? & 1950 & A & +++ & 8 \\
\hline ? Dasysiphonia sp. & NP & 1994 & A & + & 8 \\
\hline Anotrichium furcellatum Baldock & NP & 1976 & & + & 8 \\
\hline Polysiphonia senticulosa Harvey & NP & 1993 & A & + & 8 \\
\hline Polysiphonia harveyi Bailey & NP & 1908 & A & +++ & 3,8 \\
\hline \multicolumn{6}{|l|}{ Chlorophyceae (green algae) } \\
\hline Codium fragile ssp. atlanticum Silva & NP & 1839 & A & ++ & 1,3 \\
\hline Codium tragile ssp. tomentosoides Silva & NP & 1900 & $\mathrm{~A} / \mathrm{S}$ & +++ & 1,3 \\
\hline Codium fragile ssp. scandinavicum Silva & NP & 1919 & $\mathrm{~A} / \mathrm{S}$ & ++ & 1 \\
\hline
\end{tabular}


Table 1 (continued)

\begin{tabular}{|c|c|c|c|c|c|}
\hline Taxon & Origin & $\begin{array}{l}\text { First } \\
\text { record }\end{array}$ & $\begin{array}{l}\text { Trans- } \\
\text { port }\end{array}$ & Status & Ref. \\
\hline \multicolumn{6}{|l|}{ Poaceae (grasses) } \\
\hline Spartina anglica Hubbard & hybrid:WA/EA & $1890 \mathrm{~s}$ & $\mathrm{~s}$ & t+t & 3 \\
\hline \multicolumn{6}{|l|}{ Ascetospora (parasitic protozoans) } \\
\hline Bonamia ostreae Pichot et al. & WA & 1982 & A & + & 7 \\
\hline Marteilia refringens Grizel et al. & EA & $1970 \mathrm{~s}$ & A & + & 7 \\
\hline $\begin{array}{l}\text { Haplosporidium armoricanum } \\
\text { (van Banning) }\end{array}$ & EA & $1970 \mathrm{~s}$ & A & + & 7 \\
\hline \multicolumn{6}{|l|}{ Hydrozoa (hydroids) } \\
\hline Cordylophora caspia (Pallas) & Ponto-Casp. & 1884 & $\mathrm{~s}$ & $\mathrm{~b}$ & 12 \\
\hline $\begin{array}{l}\text { Gonionemus vertens Agassiz } \\
\text { (syn. murbachi Mayer) }\end{array}$ & NP & 1913 & $\mathrm{~A} / \mathrm{S}$ & + & 3 \\
\hline Garveia (Bimeria) franciscana Torrey & $?$ & 1920 & $\mathrm{~S}$ & + & 12 \\
\hline Clavopsella navis (Millard) & $?$ & 1973 & $\mathrm{~s}$ & + & 3 \\
\hline Nemopsis bachei Agassiz & WA & 1905 & s & + & 11 \\
\hline \multicolumn{6}{|l|}{ Anthozoa (sea anemones) } \\
\hline Nematostella vectensis Stephenson & WA & 1935 & & + & 6 \\
\hline $\begin{array}{l}\text { Haliplanella lineata (Verrill) } \\
\quad \text { (incl. H. luciae Verrill) }\end{array}$ & NP & 1896 & S & ++ & 3,12 \\
\hline Diadumene cincta (Stephenson) & $? \mathrm{NP}$ & 1925 & $\mathrm{~A} / \mathrm{S}$ & ++ & 9,14 \\
\hline \multicolumn{6}{|l|}{ Bivalvia (lamellibranchs) } \\
\hline $\begin{array}{l}\text { Crassostrea gigas (Thunberg) } \\
\quad \text { (incl. C. angulata) }\end{array}$ & NP & 1964 & A & ++ & 3 \\
\hline $\begin{array}{l}\text { Ensis americanus (Binney) } \\
\quad \text { (syn. directus Conrad) }\end{array}$ & WA & 1978 & $\mathrm{~S}$ & +++ & 3 \\
\hline Mytilopsis (Congeria) leucophaeta (Conrad) & EA & 1835 & $\mathrm{~s}$ & $\mathrm{~b}$ & 12 \\
\hline Mya arenaria (L.) & WA & $1250 ?$ & & t++ & 3 \\
\hline Mercenaria mercenaria (L.) & WA & 1864 & A & + & 3,12 \\
\hline Petricola pholadiformis Lamarck & WA & 1890 & A & +++ & 3 \\
\hline Teredo navalis $\mathrm{L}$. & IP & $<1800$ & $\mathrm{~S}$ & +++ & 12 \\
\hline \multicolumn{6}{|l|}{ Gastropoda (snails) } \\
\hline Corambe (obscura) batava Kerbent & WA & $1886+$ & & + & 12 \\
\hline Crepidula fornicata (L.) & WA & 1887 & A & +++ & 3 \\
\hline Urosalpinx cinerea (Say) & WA & 1900 & A & + & 3 \\
\hline $\begin{array}{l}\text { Potamopyrgus antipodarum (Gray) } \\
\text { (syn. jenkinsi) }\end{array}$ & $\mathrm{SP}$ & 1883 & $\mathrm{~S}$ & $\mathrm{~b}$ & 3,12 \\
\hline \multicolumn{6}{|l|}{ Polychaeta } \\
\hline Clymenella torquata (Leidy) & WA & 1936 & A & + & 3 \\
\hline Marenzelleria cf. viridis (Verrill) & WA & 1996 & $\mathrm{~s}$ & + & 4 \\
\hline Marenzelleria cf. wireni Augener & WA & 1982 & $\mathrm{~s}$ & t+ & 4 \\
\hline Janua brasiliensis (Grube) & WA & 1974 & $\mathrm{~S}$ & + & 3,13 \\
\hline $\begin{array}{l}\text { Pileolaria berkeleyana (Rioja) } \\
\text { (syn. rosepigmentata) }\end{array}$ & NP & 1974 & $\mathrm{~S}$ & ++ & 3,13 \\
\hline $\begin{array}{l}\text { Ficopomatus (Mercierella) enigmaticus } \\
\text { (Fauvel) }\end{array}$ & $\mathrm{SP}$ & 1921 & $\mathrm{~s}$ & ++ & 12,13 \\
\hline Hydroides dianthus (Verrill) & WA & 1970 & $\mathrm{~A} / \mathrm{S}$ & + & 3,13 \\
\hline Hydroides ezoensis Okuda & NP & 1976 & $\mathrm{~A} / \mathrm{S}$ & + & 3,13 \\
\hline Hydroides elegans (Haswell) & $?$ & 1937 & $\mathrm{~s}$ & + & 12,13 \\
\hline
\end{tabular}


Table 1 (continued)

\begin{tabular}{|c|c|c|c|c|c|}
\hline Taxon & Origin & $\begin{array}{l}\text { First } \\
\text { record }\end{array}$ & $\begin{array}{l}\text { Trans- } \\
\text { port }\end{array}$ & Status & Ref. \\
\hline \multicolumn{6}{|l|}{ Crustacea } \\
\hline Balanus amphitrite Darwin & IP & 1937 & $\mathrm{~s}$ & + & 3,12 \\
\hline Balanus improvisus Darwin & WA & 1850 & $\mathrm{~s}$ & ++ & 12 \\
\hline Balanus eburneus Gould & WA & 1900 & $\mathrm{~s}$ & + & 12 \\
\hline Elminius modestus Darwin & SP & 1943 & $\mathrm{~s}$ & +++ & 3,12 \\
\hline Eriocheir sinensis Milne-Edw. & NP & 1912 & $\mathrm{~s}$ & ++ & 3,12 \\
\hline Brachynotus sexdentatus (Risso) & EA & $?$ & $\mathrm{~S}$ & + & 6 \\
\hline Rhithropanopeus harrisii (Gould) & WA & $1870 \mathrm{~s}$ & $\mathrm{~s}$ & b & 3,12 \\
\hline Callinectes sapidus Rathbun & WA & 1932 & $\mathrm{~s}$ & + & 12 \\
\hline Caprella macho Platvoet et al. & $?$ & 1995 & & + & 12 \\
\hline Corophium sextonae Crawford & SP & $1930 \mathrm{~s}$ & & t+t & 3 \\
\hline Eusarsiella (Sarsiella) zostericola (Cushman) & WA & 1940 & A & + & 3 \\
\hline Acartia tonsa Dand & WA,IP & 1916 & $\mathrm{~s}$ & +++ & 3 \\
\hline Mytilicola orientalis Mori & NP & 1992 & A & + & 10 \\
\hline Mytilicola ostreae Hoshina \& Sugiura & NP & 1992 & A & + & 10 \\
\hline \multicolumn{6}{|l|}{ Pycnogonida (sea spiders) } \\
\hline Ammothea hilgendorii (Böhm) & NP & 1978 & S & + & 3 \\
\hline \multicolumn{6}{|l|}{ Bryozoa } \\
\hline Bugula neritina (L.) & WA & 1973 & $\mathrm{~s}$ & + & 6 \\
\hline ? Victoriella pavida Saville Kent & $?$ & 1870 & $\mathrm{~S}$ & b & 6 \\
\hline \multicolumn{6}{|l|}{ Nematoda (here: swim-bladder nematode) } \\
\hline Anguillicola crassus Kuwahara et al. & NP & 1982 & A & +++ & 3 \\
\hline Ascidiacea (sed squirts) & & & & & \\
\hline Styela clava Herdman & NP & 1952 & $\mathrm{~s}$ & +++ & 3 \\
\hline
\end{tabular}

Table 2. Number of introduced species which became established in the North Sed, and their assumed origin and mode of transport. Where two alternatives are assumed to be equally alike, a species is counted twice; if unknown no entry is made

\begin{tabular}{|lccccc|}
\hline Major & $\begin{array}{c}\text { Number } \\
\text { group }\end{array}$ & \multicolumn{2}{c}{ Origin } & \multicolumn{2}{c|}{ Imported by } \\
of species & Atlantic & Pacific & ship & aquaculture \\
\hline Phytoplankton & 9 & 1 & 8 & 5 & 3 \\
Macroaigae & 20 & 1 & 18 & 5 & 16 \\
Poaceae & 1 & 1 & - & 1 & - \\
Protozoa & 3 & 3 & - & - & 3 \\
Cnidaria & 8 & 2 & 3 & 7 & 2 \\
Mollusca & 1 & 8 & 3 & 4 & 5 \\
Annelida & 9 & 5 & 3 & 8 & 3 \\
Crustacea & 14 & 7 & 7 & 9 & 3 \\
Other invertebrates & 5 & 1 & 3 & 4 & 1 \\
\hline
\end{tabular}


the island of Sylt, which are not estuarine, the macrobenthos of approximately 300 species includes 20 exotics (Reise \& Lackschewitz, 1998, unpublished data). A share of roughly $6 \%$ is also estimated for the Dutch coast (Wolff, 1999). In offshore areas, only a few exotic species occur in the plankton. An explanation for this pattern is to be found in the availability of vectors. Mariculture and ships transport mainly organisms from coast to coast.

Although we were rather restrictive, the list of established exotics in Table 1 may erroneously include some native species, which were discovered late but may have been around long before without being noticed. As an example, Zibrowius \& Thorp (1989) mention three species of serpulids recorded from some harbors in southern England not before the 1980s, in spite of an established tradition of studying tubeworms in this region. Initially there was some suspicion that these may be exotics; however, their wide but cryptic occurrence elsewhere in the eastern Atlantic suggests that these natives were previously overlooked. Nevertheless, the number of unrecognized exotics in the North Sea is likely to exceed by far the mistaken natives, and this is for several reasons:

1. Small organisms have been poorly studied. Approximately $80 \%$ of indigenous species in the North Sea is of microscopic size $(2 \mathrm{~mm})$, while only $20 \%$ of the listed exotics belongs to this category. This discrepancy may in part be explained by a higher share of cosmopolitans among small organisms (Fenchel, 1993). On the other hand, the chance of passive transport with ships or oyster cultures is certainly increased with a decreasing individual size. Furthermore, as our attention and taxonomic expertise generally decrease with the smallness of the organisms, we believe the underrepresentation of unicellular algae, protozoans and small metazoans among the exotics to be mainly an artifact.

2. Many introductions of exotic species certainly occurred long before they were taxonomically recognized. Our list of exotics comprises only two species (the bivalves Mya arenaria and Teredo navalis) for which the date of introduction is assumed to be before 1800 . Also, in some other species, the first introduction was probably before 1800. For example, the nudibranch Corambe (obscura) batava and the crab Rhithropanopeus harrisii were described as new species from the former Zuiderzee around 1880, i.e., during the period when Dutch biologists first turned their attention to the coastal fauna of the Zuiderzee. However, at that time Dutch vessels had been sailing between Amsterdam (which used to be a Zuiderzee port) and Nieuw Amsterdam (= New York nowadays) and other American ports for nearly three centuries. Thus, the actual dates of introduction may well be long before the 1880 s when these two inconspicuous species were first discovered. The long duration of former voyages across the sea may have contributed to low survival rates of transported organisms. However, in times of wooden sailing vessels, ships had less effective antifouling strategies, and their ballast often included estuarine and marine sediments, an ideal medium for benthos to travel across the ocean (Gerlach, 1977).

3. Taxa that cannot reliably be assigned to non-native introductions have been termed 'cryptogenic species' by Carlton (1996), and only some are included in Table 1 (marked with a questionmark). An example may illustrate such a case. The large 
sandworm or king rag Nereis virens was first described by Sars in 1835 from Bergen in Norway. Nowadays this is a very conspicuous and common polychaete in the North Sea. If its distribution and abundance had been the same in the eighteenth century at the time of Carl Linnè, almost certainly he would not have missed naming this obvious worm. Instead, it was not recorded from the North Sea proper prior to 1900. Hagmeier (1925) mentioned an increasing abundance in the last decades of his time, and Rasmussen (1973) noted an invasion in a Danish fjord in the 1940s. As $N$. virens seems to be an even more prominent component of the coastal fauna on the other side of the Atlantic, it may have been introduced from there to northern Europe. Nevertheless, we still consider the evidence too weak to include $N$. virens in Table 1, because there may have been a natural spread southward from arctic waters. A genetic analysis of species with amphi-Atlantic distribution may perhaps cast some light on such cryptogenics.

In conclusion, the number of about 80 exotic species established in the North Sea is certainly an underestimate, and any ratio of exotic versus native species numbers must be restricted to macroorganisms only. In comparison to shores of other continents, it should be considered that the North Sea countries had a seafaring tradition long before naturalists began to take their records.

\section{ORIGINS AND ARRIVAL OF EXOTICS}

In terms of homoclimatic conditions, distance and frequency of seafaring, one would expect a clear dominance of exotics emanating from the other side of the Atlantic. Indeed, in the invertebrates more exotics originate from the other side of the Atlantic than from Pacific regions, particularly in molluscs and polychaetes (Table 2). However, phytoplanktonic and macroalgal exotics are almost all of Pacific origin. Besides the possibility that all potential species had been introduced long before our biological studies commenced, this difference between plants and animals may have two causes. The macroalgae of the cold and warm temperate coasts are much poorer in endemics in the western than the eastern Atlantic (Lüning, 1990). Thus, there are not many new species to be received from America. The North Pacific region, on the other hand, is very rich in endemic algal species, and the substantial imports of Pacific oysters (Chew, 1990) provided a suitable vector for attached algae and their spores, and occasionally algae are used as packing material for live oyster shipping. Transports came either directly from the western Pacific or from cultures in the eastern Pacific. The algae usually appeared first around French oyster farms, and from there most spread by their own means into the North Sea (Maggs \& Stegenga, 1999).

Although some invertebrates came by the same route, most travelled by ship (Table 2), either as larvae in ballast tanks or as adults attached to hulls. In these cases, the shorter distance and higher frequency of shipping across the Atlantic to the North Sea compared to the long voyages from the Pacific may be decisive. Furthermore, voyages from the Pacific region to Europe need to pass through tropical areas, which may affect the survival rates of species adapted to cold-temperate regions such as northern Japan. In addition, several invertebrates were introduced with American oysters (Crassostrea virginica) to the British Isles and the North Sea (Hedgpeth, 1980; Eno et al., 1997). In 
contrast to macroalgae, the macrobenthic fauna along the North American Atlantic shores does not seem to be less diverse than its counterpart on the European Atlantic shore (Briggs, 1974).

Taking all non-natives together (Table 1), up to 32 species are assumed to be introduced with American and Pacific oysters. Almost all others were probably unintentionally introduced by shipping. About 20 species have also invaded other coasts outside the European Atlantic, and thus seem to have an intrinsic aptitude to becoming introduced and then established. These species are tramping from harbor to harbor and estuary to estuary by ship or have followed the worldwide trade with Pacific oysters (Crassostrea gigas).

Within the North Sea, by far the majority of introduced exotics first became established in the south and about half of them have not yet been encountered in the north. This asymmetry may be caused by three phenomena: (1) nearly all the important ports of the North Sea are in the southern half: Le Havre, Southampton, London, Antwerp, Rotterdam, Amsterdam, Bremen and Hamburg; (2) species associated with introduced oysters tend to originate from regions with higher temperatures than from the northern North Sea, and most of these introductions occurred through the gateway of the French and southern British coasts (Korringa, 1976a, b; Chew, 1990); (3) the cold-temperate flora and fauna in the eastern and western provinces of the northern Atlantic have many species in common, while the warm-temperate biota have no close relationship between the opposite coasts because both have been geographically isolated so much longer than the biota further north (Briggs, 1974; Watling, 1979; Lüning, 1990). Thus, there is a considerably larger species pool in the warm-temperate region from which recognizable introductions may be drawn. Consequently, under climatic warming the importance of exotics in the entire North Sea could increase.

Based on shipping intensity, with volumes of ballast water increasing and passage times decreasing, the rate of introductions is expected to increase throughout the twen-

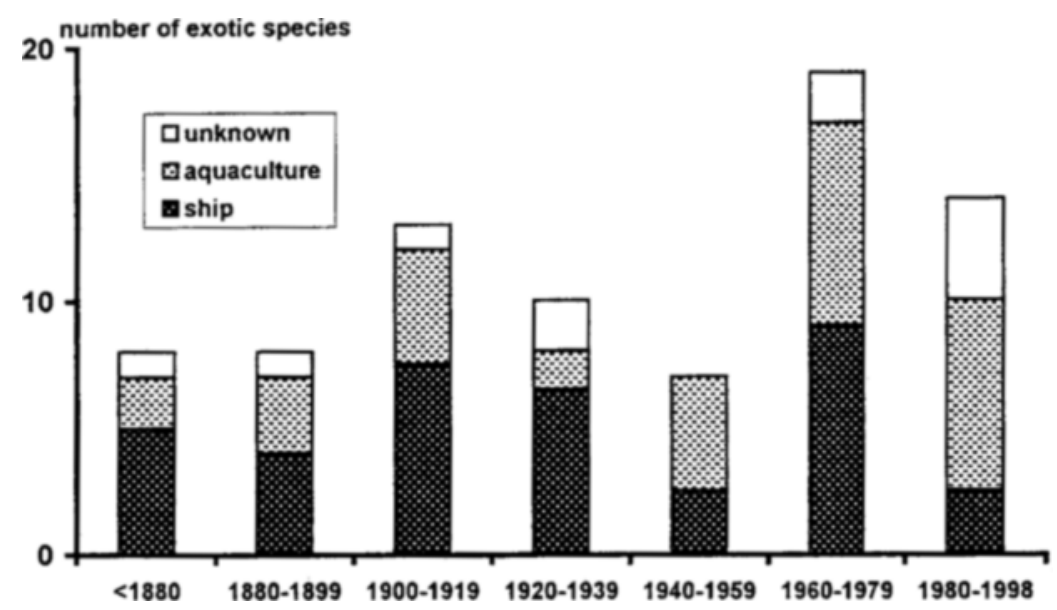

Fig. 1. Timeline of recorded North Sea introductions $(n=79)$ sorted by assumed mode of transport 
tieth century. This is exemplified by the San Francisco Bay and the Great Lakes (Mills et al., 1994; Cohen \& Carlton, 1996). The actual time course of first records from introduced species in the North Sea does not refute this trend but is less regular (Fig. 1). There is a peak in the 1970 s, which may partly be explained by imports of Crassostrea gigas and its associated organisms. These imports occurred to France, Britain and The Netherlands in the 1960s to 1970s (Korringa, 1976b). Also, the components of ship antifouling paints were changed in the 1970s. The new hull coating which containes tributyl-tinn (TBT) might be more effective compared to previously used compounds. This may have prevented a further increase in the rate of introductions since the $1970 \mathrm{~s}$ (Minchin \& Sheehan, 1995). No difference in the time course of introductions between algae and invertebrates is apparent.

\section{THE NET EFFECT OF EXOTICS}

During the last glaciation approx. 18000 years ago, surface water temperatures in the residual North Sea were about $10^{\circ} \mathrm{C}$ lower than today (McIntyre et al., 1976). Concomitant with this drop in temperature, the sea level fell by at least $110 \mathrm{~m}$, turning most of the North Sea into arctic dry land. Thus, the coastal North Sea was a hostile environment for marine organisms at that time. Recolonization from refuges may still not be complete, and the North Sea may well be below its potential contingent of species within the North Atlantic. Compared to the northern Pacific with its rich coastal flora and fauna, the entire northern Atlantic is poor in species. Transarctic interchanges during interglacial periods were highly asymmetric with almost all immigrations directed from the Pacific to the Atlantic region rather than the reverse (Vermeij, 1991). Thus, its ecological history may predispose the North Sea as a recipient area for exotic introductions from outside the Atlantic region.

What is the overall effect of the introduced exotics on the North Sea biota? Up to now, there is no evidence that exotics have driven natives to extinction. Thus, the species number in the North Sea would have been increased, if there were no extinctions caused by other means, i.e., fishing, hunting, habitat alterations or toxic substances. Locally, the numerical net balance may come close to zero (i.e., Reise, 1982), but the type of organisms is not congruent. As has been reviewed elsewhere (Williamson, 1996), not all but most of the successful invaders are generalists. Those taken up by ships should be common and abundant at harbor sites. Accordingly, they are often estuarine and well adapted to human-modified environments. To survive a long voyage, high physiological tolerance is needed, at least for some stage of the life cycle. To establish a persistent and expanding population with a small number of arrivals requires high fecundity and good means of dispersal. Exotics imported with maricultures do not need to have such properties. However, as quarantine procedures are becoming an obligatory practice in aquaculture, accidental introductions with this vector will presumably be limited to organisms with microscopic spores, resting stages or to endoparasites. Species which vanished from the North Sea coast, on the other hand, are to be found more among slow-growing, late-maturing, large-sized species with limited offspring, when fishing or hunting was the primary threat, and with narrow habitat requirements when habitat loss was the primary cause. 
The main effect of species introductions into the North Sea seems to be a species addition rather than an exchange. Some local displacements have occurred, however. A clear example is the marshgrass Spartina anglica, establishing monostands where other saltmarsh vegetation or seagrass had been before, and which greatly modifies the habitat (Meesenburg, 1975; Gray et al., 1991). In the Dutch Delta region S. anglica even displaced the former stands of S. maritima (almost) completely. In England, however, S. anglica and S. maritima rarely co-occurred, and the latter is assumed to have declined since the 1930s because of land reclamation, coastal erosion and displacement by $\mathrm{Hal}$ imione portulacoides (Gray et al., 1991). Spartina maritima may itself be an early introduction to Europe from Africa (Chevalier, 1923). It hybridized with the North American $S$. alterniflora around 1870 near Southampton, where the latter was first recorded in 1816. From the sterile hybrid $S . x$ townsendii, the new fertile species $S$. anglica originated by chromosome doubling. This is at present a widespread species in the North Sea region, but remnant populations of S. maritima, S. alterniflora and $S . \mathbf{x}$ townsendii still exist.

Near the island of Sylt in the eastern North Sea, the introduced razor clam Ensis americanus first occurred in 1979. In a sandy sediment close to the spring low tide line, macrofaunal biomass comprised $118 \mathrm{~g}$ dry organic weight $\mathrm{m}^{-2}$ in March 1993 (see Armonies \& Reise, 1998). Of this biomass, $66 \%$ was contributed by the razor clam and another $30 \%$ by the ragworm Nereis virens, suspected to be an introduced species as well (see above). The site was formerly occupied by a dense eelgrass meadow which completely fell victim to an invasive disease caused by the protist Labyrinthula zosterae in the 1930s (Wohlenberg, 1935; den Hartog, 1987). This 'wasting disease' rapidly spread on both sides of the Atlantic at that time, and may be suspected to be a human-aided invasion too. At the site near Sylt, the eelgrass never came back. The former benthic fauna was composed mainly of Lanice conchilega, Psammechinus miliaris and Littorina littore $a$ and its zoomass was probably not much higher than the $28 \mathrm{~g} \mathrm{~m}^{-2}$ of an adjacent lugworm flat in March 1993 (Reise, unpublished data). This local example may illustrate the pervasiveness of introductions on coastal North Sea biota, and the history dependence of present-day assemblages.

About 20 species of those listed in Table 1 are today widespread in the North Sea and are at least locally abundant. Except for some parasites and the shipworm Teredo navalis, economic implications of the known introductions into the North Sea are low up to now. Early in the eighteenth century the wood-boring T. navalis caused a revolution in Dutch coastal defence. Before its supposed introduction, seawalls were reinforced with wooden posts, while since then stones and other means had to be used. Contemporary people considered the 'paalworm' a plague sent by God; in consequence, prayers were said in the churches. Terodo navalis continues to cause trouble in wooden structures built into the sea until today.

\section{WHAT IS TO BE DONE ABOUT EXOTICS IN THE SEA?}

None of the exotics that have invaded the North Sea can be removed. As every introduction has the potential of unwanted and uncontrollable consequences, only preventive measures may be effective. Once a newcomer has arrived, it has to be accepted, 
and its spread can only be observed with curiosity or scientific interest to learn from its interactions with habitats, native communities as well as other exotics. These mostly inadvertent introductions have irreversibly modified the North Sea ecosystem. This is a cumulative process much faster than any natural change could ever accomplish, and enforces a progressive dethronement of the native organisms from the center of their accustomed ecological communities. Qualitatively and maybe also quantitatively, the combined effect of introduced neophytes and neozoans exceeds the more often considered environmental effects of eutrophication and toxic substances, and may rival those of the fishery in the North Sea and of habitat loss along its coastline.

In view of the fact that in the North Sea exotic species have been primarily additions rather than the cause of displacements or even extinctions, problems with the exotics may reside less in ecology and more in economy or human health. As introductions elsewhere have shown, there is always an element of risk when new species arrive. They may prey on commercially valuable species or cause diseases in species considered also to be otherwise important, including humans themselves. They may drill holes through dikes and wooden docks or infest other sensitive structures. To minimize these risks, existing quarantining protocols for maricultural organisms should be strictly adhered to. Being aware of the problem of un-intentionally introduced non-target species for aquaculture, the ICES Working Group on Introductions and Transfers on Marine Organisms developed a 'Code of Practice' listing predominantly quarantine procedures prior to and after the import of a target species. Problems are mainly with gaps in the adherence to these procedures, and more awareness, training and control is needed.

Concerning unintentionally introduced species by ballast water of ocean-going ships, the International Maritime Organization (IMO) developed guidelines to minimize the transport of species in ballast water. These are mainly based on the avoidance of ballast water uptake in shallow areas, in areas with known disease outbreaks or phytoplankton blooms, and on attempts to reduce the amount of ballast water to be discharged. Additionally, a complete mid-ocean exchange of the ballast water on board is recommended, assuming that mid-ocean species are unlikely to survive in coastal waters and vice versa. Other possible ballast water treatments are filtering and heating. Some countries (e.g. Australia, Brazil, Canada, Chile, Israel, New Zealand and the USA) require ballast water exchange or treatment prior to the release in their coastal waters. The North Sea countries should follow the ICES Code of Practice and enforce the ballast water regulations and developments by the IMO as legally binding provisions. Ballast water management also needs to be taken into account in the construction and design of new vessels.

Much remains unknown in terms of the patterns and processes of invasions. The general decline in the number of taxonomic experts is a major impediment in the identification of exotics, in monitoring their invasions and recognizing their effects. Therefore large gaps remain in the knowledge needed to establish effective management plans. Examples of research needs are:

1. Further studies on the ecology of introduced species: only a few of the introduced non-indigenous species have been the subject of quantitative and experimental studies. Particularly, their combined impact on native ecosystems cannot be esti- 
mated at present. Economic impacts of (e.g.) wood borers (shipworms and isopods) and of fouling organisms (on vessels and submerged installations) are widely unknown and remain largely undocumented and entirely unquantified.

2. Genetic studies of invaders: the application of molecular genetics has already revealed the cryptic presence of previously unrecognized invaders in the San Francisco Bay area. Studies on the polychaete Marenzelleria revealed that in fact two species, $M$. cf. viridis and $M$. cf. wireni, did invade, the former predominantly the Baltic Sea and the latter the North Sea (Essink \& Schöttler, 1997; Essink, 1999). The objective to evaluate 'hot spot areas of origin' of further species introductions may be determined more precisely by genetical comparison between introduced species and their native distribution area. Also the occurrence of secondary introductions can be proven in this way.

3. Risk assessment: as every single vessel has the potential to introduce species, it seems to be less important to estimate the total amount of ballast water discharges than to know all potential source areas of ballast water according to the shipping routes outside the North Sea. A quantitative risk assessment can be carried out for ships when sites of ballasting and deballasting are known and options for ballast water treatment have to be decided on (Hayes, 1998), and for ports where the exact profiles of ballast water sources are known. Similarly, cost/benefit analysis for planned introductions in aquaculture should be obligatory. Many aspects of invasions will remain nearly unpredictable as no answers can be given to the crucial questions: Which species will invade, when and where will it invade and what will be the impact of this new species? We know that habitats at particular risk are estuaries with international ports, waterways and shipping routes as well as aquaculture sites. They represent high risk areas for further introductions, and should be monitored accordingly.

It is false to say that every species that could have been introduced would be in the North Sea by now. The time course of introductions does not suggest a saturation level (Fig. 1). The chance of a species becoming introduced, established and then becoming a serious problem for the environment or economy at the recipient coast is small. However, one single introduced species may be able to cause severe ecological change and economic damage, and this might be the next species about to arrive.

Acknowledgements. We wish to thank the participants of the workshop on Exotic Invaders of the North Sea Shore, held on Sylt in February 1998, for contributing facts and ideas incorporated in this review. This is Alfred Wegener Institute Publication No. 1553.

\section{LITERATURE CITED}

Anderson, D. M., 1994. Red tides. - Sci. Am., August, 52-58.

Armonies, W. \& Reise, K., 1998. On the population development of the introduced razor clam Ensis americanus near the island of Sylt (North Sea). - Helgoländer Meeresunters. 52.

Bertness, M. D., 1984. Habitat and community modification by an introduced herbivorous snail. Ecology 65, 370-381.

Brenchley, G. A. \& Carlton, J. T., 1983. Competitive displacement of native mud snails by introduced periwinkles in the New England intertidal zone. - Biol. Bull. 165, 543-558.

Briggs, J. C., 1974. Marine zoogeography. - McGraw-Hill, New York, 475 pp. 
Carlton, J. T., 1985. Transoceanic and interoceanic dispersal of coastal marine organisms: the biology of ballast water. - Oceanogr. Mar. Biol. Annu. Rev. 23, 313-371.

Carlton, J. T., 1989. Man's role in changing the face of the ocean; biological invasions and implications for conservation of near-shore environments. - Conserv. Biol. 3, 265-273.

Carlton, J. T., 1996. Biological invasions and cryptogenic species. - Ecology 77, 1653-1655.

Carlton, J. T. \& Geller, J. B., 1993. Ecological roulette: the global transport of nonindigenous marine organisms. - Science $261,78-82$.

Carlton, J. T., Thompson, J. K., Schemel, L. E. \& Nichols, F. H., 1990. Remarkable invasion of San Francisco Bay (California, USA) by the Asian clam Potamocorbula amurensis. I. Introduction and dispersal. - Mar. Ecol. Prog. Ser. 66, 81-94.

Ceccherelli, G. \& Cinelii, F., 1997. Short-term effects of nutrient addition and interactions between the seagrass Cymodocea nodosa and the introduced green alga Caulerpa taxifolia in a Mediterranean bay. - J. Exp. Mar. Biol. Ecol. 217, 165-177.

Chapman, A. S., 1999. From introduced species to invader; what determines variation in the success of Codium fragile ssp. tomentosoides (Chlorophyta) in the North Atlantic Ocean. - Helgoländer Meeresunters. 52.

Chevalier, A., 1923. Note sur les Spartina de la flore française. - Bull. Soc. Bot. Fr. 70, 54-63.

Chew, K. K., 1990. Global bivalve shellfish introductions. - World Aquaculture 21, 9-24.

Cohen, A. N. \& Carlton, J. T., 1996. Nonindigenous species in a United States estuary: a case history of the ecological and economic effects of biological invasions in the San Francisco and Delta region. - Report to the US Fish \& Wildlife Service, 246 pp. (+ appendices).

de Villèle, X. \& Verlaque, M., 1995. Changes and degradation in a Posidonia oceanica bed invaded by the introduced tropical alga Caulerpa taxifolia in the north western Mediterranean. - Bot. Mar. 38, 79-87.

Elbrächter, M., 1999. Exotic flagellates of coastal North Sed waters. - Helgoländer Meeresunters. 52.

Eno, N. C., Clark, R. A. \& Sanderson, W. G., 1997. Non-native marine species in British waters: cl review and directory. Joint Nature Conservation Committee, Peterborough, $152 \mathrm{pp}$.

Essink, K., 1999. Dispersal and development of Marenzelleria spp. (Polychaeta, Spionidae) populations in NW Europe and The Netherlands. - Helgoländer Meeresunters. 52

Essink, K. \& Schöttler, U. (eds), 1997. Studies on Marenzelleria spp. (Polychaeta: Spionidae). Aquat. Ecol. 31, 117-258.

Fenchel, T., 1993. There are more small than large species? - Oikos 68, 375-378.

Fletcher, R. L. \& Farrell, P., 1999. Introduced brown algae in the North East Atlantic, with particular respect to Undaria pinnatifida (Harvey) Suringar. - Helgoländer Meeresunters. 52.

Gerlach, S. A., 1977. Means of meiofauna dispersal. - Mikrofauna Meeresboden 61, 89-103.

Gollasch, S., 1996. Untersuchungen des Arteintrages durch den internationalen Schiffsverkehr unter besonderer Berücksichtigung nichtheimischer Arten. - Verlag Dr. Kovac, Hamburg, 210 pp.

Gollasch, S. \& Riemann-Zürneck, K., 1996. Transoceanic dispersal of benthic macrofauna: Haliplanella luciae (Verrill, 1898) (Anthozoa, Actiniaria) found on a ship's hull in a shipyard dock in Hamburg Harbour, Germany. - Helgoländer Meeresunters. 50, 253-258.

Gray, A. J. D., Marshall, D. F. \& Raybould, A. F., 1991. A century of evolution in Spartina anglica. - Adv. Ecol. Res. 21, 1-62.

Grosholz, E. D. \& Ruiz, G. M., 1995. Spread and potential impact of the recently introduced European green crab, Carcinus maenas, in central California. - Mar. Biol. 122, 239-247.

Hagmeier, A., 1925. Vorläufiger Bericht über die vorbereitenden Untersuchungen der Bodenfauna der Deutschen Bucht mit dem Petersen-Bodengreifer. - Ber. Dtsch. Wiss, Komm. Meeresforsch., Neue Folge 1, 247-272.

Hartog, C. den, 1987. "Wasting disease" and other dynamic phenomena in Zostera beds. - Aquat. Bot. 27, 3-14.

Hayes, K. R., 1998. Ecological risk assessment for ballast water introductions: a suggested approach. - ICES J. Mar. Sci. 55, 201-212.

Hayward, P. J. \& Ryland, J. S., 1990. The marine fauna of the British Isles and NW-Europe. Clarendon Press, Oxford, 996 pp. 
Hedgpeth, J.W., 1980. The problem of introduced species in management and mitigation. - Helgoländer Meeresunters. 33, 662-673.

Jansson, K., 1994. Alien species in the marine environment: introductions to the Baltic Sea and the Swedish West Coast. - Swedish Environmental Protection Agency, Solna, Sweden, 68 pp.

Kimmerer, W. J., Gartside, E. \& Orsi, J. J., 1994. Predation by an introduced clam as the likely cause of substantial declines in zooplankton of San Francisco Bay. - Mar. Ecol. Prog. Ser. 113, 81-93.

Kinne, O., 1984. Diseases of marine animals, vol. IV, Part 1. Biologische Anstalt Helgoland, Ham. burg, $541 \mathrm{pp}$.

Kinzelbach, R., 1995. Neozoans in European waters - exemplifying the worldwide process of invasion and species mixing. - Experientia 51, 526-538.

Korringa, P., 1976 a. Farming the flat oysters of the genus Ostrea.-Elsevier, Amsterdam, 238 pp.

Korringa, P., 1976 b. Farming the Cupped oysters of the genus Crassostrea. - Elsevier, Amsterdam, $224 \mathrm{pp}$.

Lauckner, G., 1983. Diseases of marine Mollusca: Bivalvia. In: Diseases of marine animals, vol. II. Ed. by O. Kinne. Biologische Anstalt Helgoland, Hamburg, 477-961.

Lüning, K., 1990. Seaweeds, their environment, biogeography, and ecophysiology. - Wiley, New York, $527 \mathrm{pp}$.

Maggs, C. A. \& Stegenga, H., 1999. Red algal exotics on North Sea coasts. - Helgoländer Meeresunters. 52

McIntyre, C. D. et al. (CLIMAP project members), 1976. The surface of the ice-age earth. - Science 191, 1131-1137.

Meesenburg, H., 1975. Spartinas kolonisationlangs Ho Bugt. - Geogr. Tidskr. 71, 37-45.

Mills, E. L., Leach, J. H., Carlton, J. T. \& Secor, C. L., 1994. Exotic species and the integrity of the Great Lakes. - BioScience 44, 666-676.

Minchin, D. \& Sheehan, J., 1995. The significance of ballast water in the introduction of exotic marine organisms to Cork Harbour, Ireland. - ICES Annual Science Conference, Aalborg, Denmark, Session O:1, 15 pp.

Möbius, K., 1877. Die Auster und die Austernwirthschaft. Wiegandt, Hempel \& Parey, Berlin, 126 pp.

Nehring, S., 1998. Non-indigenious phytoplankton species in the North Sea: supposed region of origin and possible transport vector. - Arch. Fish. Mar. Res. 46, 181-194.

Nehring, S. \& Leuchs, H., 1999. Neozoa (Makrozoobenthos) an der deutschen Nordseeküste: eine Übersicht. - Bundesanstalt für Gewässerkunde, Koblenz, Bericht BfG-1200, 131 pp.

Nichols, F. H., Thompson, J. K. \& Schemel, L. E., 1990. Remarkable invasion of San Francisco Bay (California, USA) by the Asian clam Potamocorbula amurensis. Il. Displacement of a former community. - Mar. Ecol. Prog. Ser. 66, 95-101.

North Sea Task Force, 1993. North Sea Quality Status Report 1993. Oslo and Paris Commissions, London. Olsen \& Olsen, Fredensborg, Denmark, $132+$ vi pp.

Rasmussen, E., 1973. Systematics and ecology of the Isefjord marine fauna (Denmark). - Ophelia $11,1-495$

Reise, K., 1982. Long-term changes in the macrobenthic invertebrate fauna of the Wadden Sea: are polychaetes about to take over? - Neth. J. Sea Res. 16, 29-36.

Reise, K. \& Lackschewitz, D., 1998. Benthos des Wattenmeeres zwischen Sylt und Rømø. In: Ökosystem Wattenmeer, Austausch-, Transport- und Stoffumwandlungsprozesse. Ed. by C. Gätje \& K. Reise. Springer, Berlin Heidelberg New York, 55-64.

Ruiz, G. M., Carlton, J. T., Grosholz, E. D. \& Hines, A. H., 1997. Global invasions of marine and estuarine habitats by non-indigenous species: mechanisms, extent, and consequences. - Am. Zool. 37, 621-632.

Stock, J.H., 1993. Copepoda (Crustacea) associated with commercial and non-commercial Bivalvia in the East Scheldt, The Netherlands. - Bijdr. Dierk. 63, 61-64.

Thiel, H., 1968. Die Einwanderung der Hydromeduse Nemopsis bachei L. Ag, aus dem ostamerikanischen Küstengebiet in die westeuropäischen Gewässer und in die Elbmündung. Abh. Naturwiss. Ver. Hamburg, N.F.12, 81-94. 
Travis, J., 1993. Invader threatens Black and Azov Seas. - Science 262, 1366-1367.

Vermeij, G. J., 1991. When biotas meet: understanding biotic interchange. - Science 253, 1099-1104.

Watling, L., 1979. Zoogeographic affinities of northeastern North America gammaridean Amphipoda. - Bull. Biol. Soc. Wash. 3, 256-282.

Williamson, M., 1996. Biological invasions. Chapman \& Hall, London, 244 pp.

Wohlenberg, E., 1935. Beobachtungen über das Seegras, Zostera marina L., und seine Erkrankung im nordfriesischen Wattenmeer. - Nordelbingen 11, 1-19.

Wolff, W. J., 1999. Exotic invaders of the meso-oligohaline zone of estuaries in The Netherlands: why are there so many? - Helgoländer Meeresunters. 52.

Zibrowius, H. \& Thorp, C. H., 1989. A review of the alien serpulid and spirorbid polychaetes in the British Isles. - Cah. Biol. Mar. 30, 271-285. 